\title{
Determination of the Methylpheophorbide a Association Degree by Diffusion Ordered NMR Spectroscopy (DOSY)
}

\author{
A. L. Stolypko, ${ }^{a, b}$ and Dmitry V. Belykh ${ }^{a @}$ \\ a'Institute of Chemistry, Komi Scientific Center, Ural Division, Russian Academy of Sciences, 167982 Syktyvkar, Russian \\ Federation \\ ${ }^{\mathrm{b}}$ Syktyvkar State University, 167000 Syktyvkar, Russian Federation \\ ${ }^{\circledR}$ Corresponding authorE-mail: belykh-dv@mail.ru
}

\begin{abstract}
The behavior of methylpheophorbide a in solution was studied by diffusion ordered NMR spectroscopy (DOSY), and its molecule association degree was estimated. It was found that methylpheophorbide a associates consist of an average of 4-5 molecules at room temperature. When the temperature increases the associate's size decreases, and at 50-55 ${ }^{\circ} \mathrm{C}$ the associate's size approaches to the size of the monomer.
\end{abstract}

Keywords: Methylpheophorbide $a$, Diffusion Ordered NMR Spectroscopy (DOSY), association.

\section{Определение степени ассоциации метилфеорорбида $a$ методом DOSY}

\author{
А. $\lambda$. Столыпко, а,b A. В. Белых ${ }^{\mathrm{a}}$

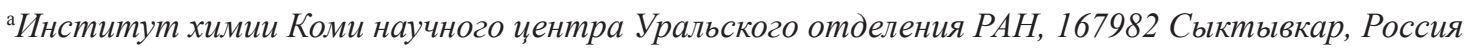 \\ ${ }^{\mathrm{b}}$ Сыктывкарский государственный университет, 167000 Сыктывкар, Россия \\ ${ }^{\circledR}$ E-mail: belykh-dv@mail.ru
}

\begin{abstract}
Методом ядерной магнитной диффузионно-ориентированной спектроскопии (DOSY) изучено состояние метилфеофорбида а в растворе, и выполнена оценка степени ассоциации его молекул. Установлено, что при комнатной температуре ассочииаты метилфеофорбида а состоят в среднем из 4-5 молекул. При повышении температуры размеры ассочиатов уменьшаются и при 50-55 ㄷ приближаются к размерам мономера.
\end{abstract}

Ключевые слова: Метилфеофорбид $а$, диффузионно ориентированная ЯМР спектроскопия (DOSY), ассоциация.

\section{Introduction}

It is known that porphyrin compounds play an important role in nature and find wide application in various fields. Therefore, intensive studies on the synthesis and chemical reactions of natural and synthetic porphyrin compounds are carried out as well as the study of their properties (optical, catalytic, and biological, etc.). One of the most important properties of porphyrin compounds is their tendency to association in solutions. ${ }^{[1-3]}$ Reliable information about the porphyrin association processes is essential in the planning of the synthesis and chemical modification of these compounds for practical and scientific applications.
The association of natural and synthetic porphyrins is of great importance in a variety of processes. The associate formation affects on the reactivity of porphyrins in solutions. An important characteristic of the association processes is the molecules number forming an associate (the association degree). The average number of molecules in the associate can be estimated by DOSY method (diffusion ordered NMR spectroscopy) which allows to directly determine the self-diffusion coefficients D of molecules in solution. ${ }^{[4-7]}$ It is known that DOSY method can be used for study of the molecules association in a solution, this method allows to fix the formation of molecular associates with relatively strong hydrogen bonds or ionic interactions between molecules. ${ }^{[8-10]}$ 
DOSY method was also used for multiporphyrin systems molecular weights estimation, but the porphyrin macrocycles in the objects of these investigations are connected with involvement of covalent bonds, ${ }^{[1]}$ or through strong coordination interactions, ${ }^{[12-17]}$ or hydrogen bonds. ${ }^{[18]}$ The porphyrin associates with weaker intermolecular interactions have not been investigated by this method. We have studied the methylpheophorbide $a$ (1) (Figure 1) behavior in solution, and its molecule association degree was estimated by DOSY measurement at various temperatures.
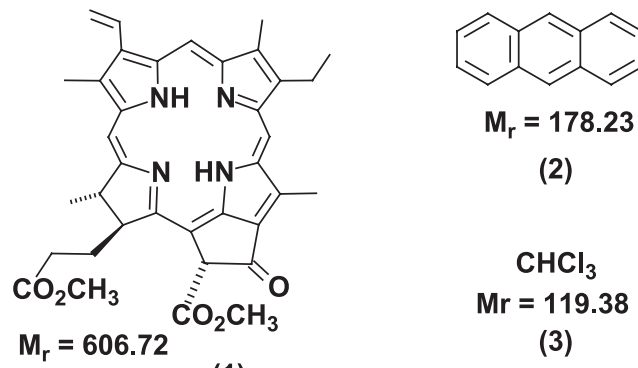

(1)

Figure 1. The structures and the relative molecular mass of the investigated compounds ((1) - methylpheophorbide $a$, (2) - anthracene, (3) - chloroform).

\section{Experimental}

Methylpheophorbide a (1) was obtained from the lipid fraction of Serratula coronata extractives. ${ }^{[19]}$ Chemically pure grade anthracene (2) (Reakhim) was used without further purification. The measurements were carried out on Bruker Avance II spectrometer $(300 \mathrm{MHz})$. The methylpheophorbide $a$ and anthracene concentrations in the $\mathrm{CDCl}_{3}$ solution tested were 2.2 and $1 \mathrm{mg}$ per $\mathrm{ml}$ respectively. The solution height in the ampule was $40 \mathrm{~mm}$. 1: ${ }^{1} \mathrm{H} \mathrm{NMR}\left(300 \mathrm{MHz}, \mathrm{CDCl}_{3}, 25^{\circ} \mathrm{C}\right) \delta_{\mathrm{H}} \mathrm{ppm}$ : $9.60\left(\mathrm{~s}, 1 \mathrm{H}, \mathrm{H}^{10}\right), 9.46\left(\mathrm{~s}, 1 \mathrm{H}, \mathrm{H}^{5}\right), 8.63\left(\mathrm{~s}, 1 \mathrm{H}, \mathrm{H}^{20}\right), 8.04[\mathrm{~m}, 1 \mathrm{H}$, $\left.3-\left(\mathrm{CH}=\mathrm{CH}_{2}\right)\right], 6.33\left[\mathrm{~d}, 1 \mathrm{H}, 3-\left(\mathrm{CH}=\mathrm{CH} H_{\text {trans }}\right), J=18.3 \mathrm{~Hz}\right], 6.30$ $\left(\mathrm{s}, 1 \mathrm{H}, \mathrm{H}^{13(2)}\right), 6.23\left[\mathrm{~d}, 1 \mathrm{H}, 3-\left(\mathrm{CH}=\mathrm{CH} H_{\text {cis }}\right), J=11.0 \mathrm{~Hz}\right], 4.51$ (q, $1 \mathrm{H}, \mathrm{H}^{18}, J=6.6 \mathrm{~Hz}$ ), 4.25 (br. d, $1 \mathrm{H}, \mathrm{H}^{17}, J=8.1 \mathrm{~Hz}$ ), 3.91 (s, $3 \mathrm{H}$, 13(2)- $\mathrm{COOCH}_{3}$ ), 3.74 (q, $2 \mathrm{H}, 8-\mathrm{CH}_{2} \mathrm{CH}_{3}, J=7.3 \mathrm{~Hz}$ ), 3.73 (s, $3 \mathrm{H}$, $\left.17-\mathrm{CH}_{2} \mathrm{CH}_{2} \mathrm{COOCH}_{3}\right), 3.61\left(\mathrm{~s}, 3 \mathrm{H}, 12-\mathrm{CH}_{3}\right), 3.45\left(\mathrm{~s}, 3 \mathrm{H}, 2-\mathrm{CH}_{3}\right)$, $3.28\left(\mathrm{~s}, 3 \mathrm{H}, 7-\mathrm{CH}_{3}\right), 2.75-2.47\left[\mathrm{~m}, 2 \mathrm{H}, 17-\left(\mathrm{CH}_{2} \mathrm{CH}_{2} \mathrm{COOCH}_{3}\right)\right]$, 2.44-2.19 [m, 2H, 17- $\left.\left(\mathrm{CH}_{2} \mathrm{CH}_{2} \mathrm{COOCH}_{3}\right)\right], 1.85\left(\mathrm{~d}, 3 \mathrm{H}, 18-\mathrm{CH}_{3}\right.$, $J=7.3 \mathrm{~Hz}$ ), 1.74 (t, 8- $\mathrm{CH}_{2} \mathrm{CH}_{3}, J=7.3 \mathrm{~Hz}$ ), 0.59 (br.s, $1 \mathrm{H}, \mathrm{I}-\mathrm{NH}$ ), -1.60 (br.s, $1 \mathrm{H}, \mathrm{III}-\mathrm{NH}) .2$ : ${ }^{1} \mathrm{H}$ NMR $\left(300 \mathrm{MHz}, \mathrm{CDCl}_{3}, 25^{\circ} \mathrm{C}\right) \delta_{\mathrm{H}}$ ppm: $8.46\left(\mathrm{~s}, 2 \mathrm{H}, \mathrm{H}^{9}, \mathrm{H}^{10}\right), 8.04\left(\mathrm{~m}, 4 \mathrm{H}, \mathrm{H}^{1}, \mathrm{H}^{4}, \mathrm{H}^{5}, \mathrm{H}^{8}\right), 7.50(\mathrm{~m}, 4 \mathrm{H}$, $\left.\mathrm{H}^{2}, \mathrm{H}^{3}, \mathrm{H}^{6}, \mathrm{H}^{7}\right)$. The DOSY experiment parameters for the program stebpgp1s: D $20=0.1 \mathrm{~s}$; P $30=1600 \mu \mathrm{s} ; \mathrm{NS}=16$; td $(\mathrm{F} 1)=32$. The experiments were carried out at various stabilized temperatures in the range of $10-55^{\circ} \mathrm{C}$ (Table 1), using an air cushion for external vibrations influence reducing. The gas flow rate in a thermostat was $670 \mathrm{l} / \mathrm{h}$, the purging was carried out by air at room temperature and at temperatures above, when temperature was lower than room temperature the purging was carried out by nitrogen.

\section{Results and Discussion}

We have studied the resizing of molecular associates formed by porphyrin when temperature changes to assess the methylpheophorbide $a \mathbf{1}$ association degree. The associates sizes was determined relative to fiducials compounds (chloroform and anthracene) by the measuring of self-diffusion coefficient $\mathrm{D}$ of all contained in a solution molecules by DOSY method (Table 1). The assessment of the association degree was performed with the obvious assumption that the average number of molecules in the associates decreases as the temperature rises, and at achievement of a certain temperature, there is a complete destruction of the associates. Since this temperature and its further increasing the associates degenerate into monomers, and sizes of methylpheophorbide $a$ formed particle will not be further changed. It allows to experimentally determine the temperature of the transition to the monomeric state of

Table 1. The self-diffusion coefficients D of methylpheophorbide $a(\mathbf{1})$, anthracene (2), and chloroform (3) at different temperatures.

\begin{tabular}{|c|c|c|c|c|c|c|c|c|}
\hline \multirow[t]{2}{*}{$\mathrm{T},{ }^{\circ} \mathrm{C}$} & \multicolumn{3}{|c|}{$\begin{array}{l}\text { The measured } \\
\text { self-diffusion coefficients } \\
\left(\mathrm{D}_{\mathrm{m}} \cdot 10^{10} \mathrm{~m}^{2} / \mathrm{s}\right)\end{array}$} & \multicolumn{3}{|c|}{$\begin{array}{l}\text { Self-diffusion coefficients, } \\
\text { adjusted for convection } \\
\left(\mathrm{D}_{\text {corr }} \cdot 10^{10} \mathrm{~m}^{2} / \mathrm{s}\right)\end{array}$} & \multicolumn{2}{|c|}{$\begin{array}{c}\text { The effective size ratio } \\
\text { (the average number of } \\
\text { molecules of } \mathbf{1} \text { or } \mathbf{2} \text { in } \\
\text { associate) }\end{array}$} \\
\hline & 1 & 2 & 3 & 1 & 2 & 3 & $1 / 3$ & $2 / 3$ \\
\hline 10 & 1.6 & 2.3 & 3.3 & 0.4 & 1.1 & 2.1 & 145 (12) & $7.0(3)$ \\
\hline 13 & 1.2 & 2.0 & 3.0 & 0.4 & 1.2 & 2.2 & $166(14)$ & $6.0(3)$ \\
\hline 16 & 0.9 & 1.8 & 2.7 & 0.5 & 1.4 & 2.3 & $97(8)$ & $4.4(2)$ \\
\hline 19 & 0.8 & 1.6 & 2.6 & 0.6 & 1.4 & 2.4 & $64(5)$ & $5.0(2)$ \\
\hline 22 & 0.7 & 1.6 & 2.5 & 0.6 & 1.5 & 2.4 & $64(5)$ & $4.0(2)$ \\
\hline 25 & 0.7 & 1.7 & 2.6 & 0.7 & 1.7 & 2.6 & $51(4)$ & $3.6(2)$ \\
\hline 28 & 0.9 & 1.9 & 2.8 & 0.8 & 1.8 & 2.7 & $38(3)$ & $3.3(2)$ \\
\hline 31 & 1.0 & 2.0 & 3.0 & 0.9 & 1.8 & 2.8 & $30(3)$ & $3.8(2)$ \\
\hline 34 & 1.2 & 2.3 & 3.2 & 0.9 & 2.0 & 2.9 & $33(3)$ & $3.1(1)$ \\
\hline 37 & 1.4 & 2.4 & 3.4 & 1.0 & 2.0 & 3.0 & $27(2)$ & $3.4(2)$ \\
\hline 40 & 1.5 & 2.6 & 3.6 & 1.0 & 2.2 & 3.1 & $30(3)$ & $2.8(1)$ \\
\hline 45 & 1.9 & 3.2 & 4.0 & 1.1 & 2.5 & 3.3 & 27 (2) & $2.3(1)$ \\
\hline 50 & 2.4 & 3.6 & 4.4 & 1.4 & 2.7 & 3.5 & $16(1)$ & $2.1(1)$ \\
\hline 55 & 3.1 & 4.2 & 5.1 & 1.6 & 2.8 & 3.7 & $12(1)$ & $2.3(1)$ \\
\hline
\end{tabular}


the porphyrin (temperature of associates destruction). The effective size of the molecules at this temperature is equal to the monomer effective size and further comparing of the molecules effective size of the compounds studied at different temperatures gives an indication of the association degree changing with the temperature variation. It should be noted that it is not necessary to know the absolute size of the particles formed by the porphyrin in solution to solve this problem. It is enough to determine the relative change of the associates effective size. It can be done by comparing the $\mathrm{D}$ values of the test compound with coefficients $\mathrm{D}$ of substances that are not inclined to the association in solution. According to the well-known Einstein-Stokes equation:

$$
D=\frac{k_{B} T}{6 \pi \eta r}
$$

where $\mathrm{k}_{\mathrm{B}}$ is Boltzmann constant, $\mathrm{T}$ is absolute temperature, $\eta$ is viscosity coefficient, and $r$ is the hydrodynamic radius of the particle. Thus, the volume ratio $\mathrm{V}$ of molecules such as $\mathbf{1}$ and $\mathbf{3}$ is equal to:

$$
\frac{V(1)}{V(3)}=\left(\frac{r(1)}{r(3)}\right)^{3}=\left(\frac{D(3)}{D(1)}\right)^{3}
$$

The accurate measurement of the associates true size is very difficult in routine DOSY experiment. The Einstein-Stokes equation provides only estimated values in assuming spherical particle shape, the complete absence of convection, temperature gradients, the solvation shell and number of well-known assumptions. ${ }^{[6,7]}$ However, the ratio of the effective volumes determining is much more simple task which is feasible on a routine equipment. By comparing the effective volumes of the compounds not prone and prone to association in the solution, we can try to fix the association of the latter. The compounds not prone to the association can be selected as the reference, in this case they are anthracene and undeuterated chloroform contained in deuterated (since the concentration of nondeuterated chloroform in deuterated one is sufficient for measurements, additional $\mathrm{CHCl}_{3}$ was not added). Anthracene is in some measure geometric analog of porphyrin (it is aromatic molecule which hydrodynamic shape is quite acceptable to the spherical approximation, and it is clear from the chemical structure that it is much less prone to form associates no groups in the molecule capable of forming strong hydrogen bonds may only staking interaction). Chloroform was also selected as a reference compound, since it does not form associates and, in addition, to achieve the purpose of the experiment determining the true scope of the particles is not required despite the difference in size of the molecule and its composition.

At temperatures different from the room temperature, the measurement results of the coefficient $\mathrm{D}$ may be distorted the existence of convection (see Table 1). To obtain correct results it is necessary to weaken the convection processes. It is necessary to divide the diffusion and convective contributions to the motion of molecules, because of it seems to be almost impossible to completely get rid of convection. To minimize convective currents, we have used a capillary tube disposed along the axis of the ampoule (capillary diameter is $1.5 \mathrm{~mm}$ for a standard ampule internal diameter $4.2 \mathrm{~mm}$ ). Despite of the sample volume decreasing, the presence of such a capillary does not lead to a significant reduction of the NMR signal at signal/noise ratio and allows experiments DOSY at quite an acceptable increase of the signals accumulation time. The solvent evaporation during the experiment can also induce convective flows, especially at high temperatures. They are related to concentrations equalization in the surface layers, where evaporation takes place, with the bulk solution. The tube was hermetically sealed by parafilm to reduce the evaporation of chloroform. As a result, the sample volume was not change during the experiments as well as for a time of about a week or more. Thus the evaporation and the related convection processes were reduced to a minimum. The measures taken have allowed to eliminate the convection influence and to the extent that has allowed the coefficients D measurements with accuracy of about $10 \%$ (measuring accuracy was estimated relative peak width ratio $\mathrm{D}$ on the two-dimensional spectrum DOSY in relation to the value of $\mathrm{D}$ to the peak).

Accounting for the remaining convective flow has been made according to the following procedure. Since in our DOSY experiments we have used the samples mode of thermostating before the experiment starting and the sample was heated at a predetermined temperature for at least 20 minutes, the convective flow in the sample can be considered as stationary. The estimation DOSY experiments to measure the ratio D in the process of thermal stabilization were conducted to test the convection currents stationary. The measurements have shown that 15 minutes are sufficient time for D value varied no more than $10 \%$ when heat setting time increases. For stationary convective currents at a certain temperature it is naturally assumed that the convection velocity of components with different weight and a structure will be the same in solution. It is also reasonable to assume that at room temperature, in the absence of temperature gradients and minimize of evaporation, the convection contribution to the coefficient $\mathrm{D}$ value is minimal. Disregarding this contribution, we can use the selfdiffusion coefficient at room temperature to calculate the temperature dependence D $(\mathrm{T})$ for the reference compounds. This can be done based on Einstein-Stokes equation and on the known viscosity temperature dependence of the solvent. ${ }^{[20]}$ The experimental temperature dependence of $\mathrm{D}$ will differ from the calculated on the value of the convection contribution $\mathrm{D}_{\mathrm{c}}(\mathrm{T})$. Thus, subtracting from the experimental dependence $\mathrm{D}$ the reference substances (chloroform and/ or anthracene) calculated dependence of the reference substance, we obtain the temperature dependence of the common to all compounds convection contribution $\mathrm{D}_{\mathrm{c}}(\mathrm{T})$. Subtracting the description of the experimental curve $\mathrm{D}$ for porphyrin the temperature dependence $\mathrm{D}_{\mathrm{c}}(\mathrm{T})$ is obtained above temperature dependence of $\mathrm{D}$ for a given sample considering the convection, i.e. the revised values of porphyrin self-diffusion coefficients at different temperatures were obtained. Coefficients D corrected according to the procedure described above and ratio of methylpheophorbide $a$, anthracene and chloroform effective sizes calculated from the data obtained are presented in Table 1.

Analysis of the data obtained leads to the following conclusions. The presence of three well-resolved peaks on the diffusion axis correlated with methylpheophorbide $a$, anthracene and chloroform peaks in the ${ }^{1} \mathrm{H}$ NMR spectrum 


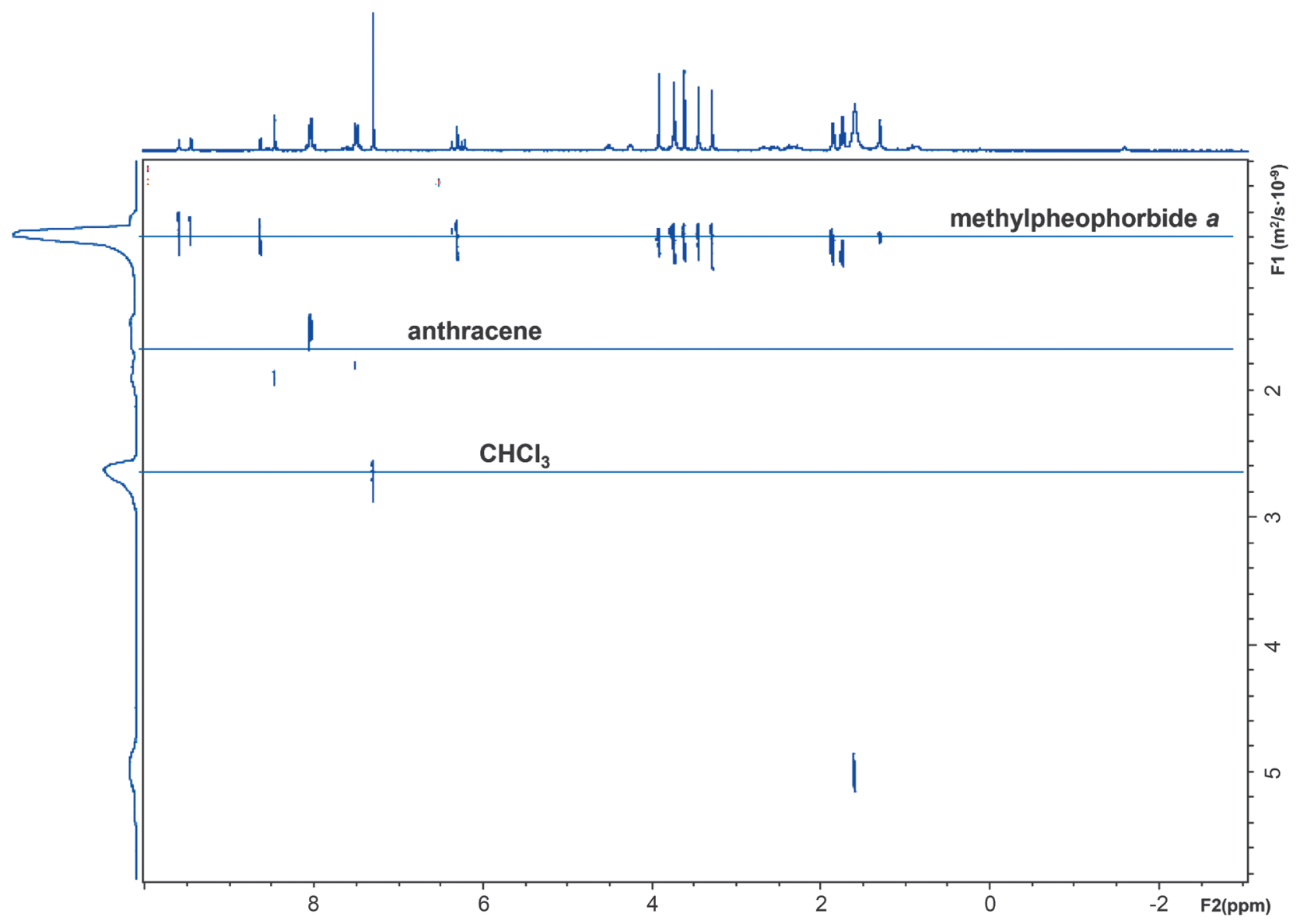

Figure 2. Two-dimensional DOSY spectrum of methylpheophorbide $a$ and anthracene solution in $\mathrm{CDCl}_{3}$ at $25^{\circ} \mathrm{C}$.

suggests that available in solution compounds do not form associates, consisting of different molecules (e.g., methylpheophorbide $a$ and anthracene or methylpheophorbide $a$ and chloroform, Figure 2). Therefore, if there are association processes, it is self-association in any case. Chloroform possesses the lowest propensity to associate among all com-

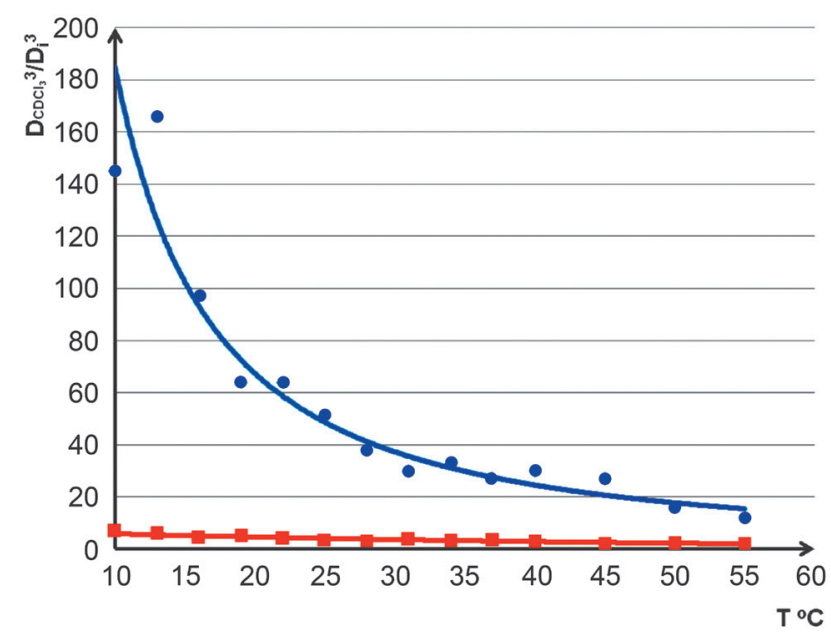

Figure 3. The methylpheophorbide $a \mathbf{1}$ effective volume $\left(\mathrm{D}_{\mathrm{CHCl}_{3}}{ }^{3} / \mathrm{D}_{1}{ }^{3} ; \bullet\right)$ and anthracene $2\left(\mathrm{D}_{\mathrm{CHCl}_{3}}{ }^{3} / \mathrm{D}_{2}{ }^{3} ; \mathbf{\square}\right)$ dependence on temperature. pounds contained in the solution. This can be seen by the weakest temperature dependence of chloroform self-diffusion coefficient D compared to anthracene and porphyrin. The strong temperature dependence of $\mathrm{D}$ for the porphyrin is due, apparently, the destruction of its associates with increase of temperature. Other variants are difficult for explaination from a chemical point of view. For example, we assume that the effective sizes of the associates formed by methylpheophorbide $a$ and anthracene do not change, the effective size of chloroform and towards methylpheophorbide $a$, and in relation to anthracene increases with increasing temperature. Obviously, this does not correspond to the generally accepted ideas about the association processes. Despite the limited possibilities of the intermolecular interaction in the case of anthracene at low temperatures the formation of an associate in the average of the three molecules is also observed. Therefore best reference compound in this experiment is chloroform. Comparing the size of particle formed by methylpheophorbide $a \mathbf{1}$ with a size of particle formed by anthracene $\mathbf{2}$ and chloroform $\mathbf{3}$ it is able to record strong decrease of the particle size formed by porphyrin 1 with increasing of temperature (Figure 1). The greatest changes were observed in the case of a methylpheophorbide $a$. Dependencies of $\mathrm{D}_{\mathrm{CHCl}_{3}}{ }^{3} / \mathrm{D}_{1}{ }^{3}$ and $\mathrm{D}_{\mathrm{CHCl}_{3}} / \mathrm{D}_{2}{ }^{3}$ on temperature are exponential (Figure 3 ), that corresponds to the desire for the complete destruction of the associates with increasing temperature, and the exponential growth of mol- 
ecules number in the associate with temperature decreasing (in practice it means crystallization center formation followed by solid phase formation in the case of insufficient solubility of compound $\mathbf{1}$, or freezing of the solvent). It can serve as an additional argument in favor of using the effective volumes of methylpheophorbide $a \mathbf{1}$ and anthracene $\mathbf{2}$ (measured as $\mathrm{D}_{\mathrm{CHCl}_{3}}{ }^{3} / \mathrm{D}_{1}{ }^{3}$ and $\mathrm{D}_{\mathrm{CHCl}_{3}}{ }^{3} / \mathrm{D}_{2}{ }^{3}$ respectively) as a quantitative measure of the association $\mathbf{1}$ and $\mathbf{2}$. Weak dependence on temperature of $\mathbf{1}$ and $\mathbf{2}$ effective dimensions at region of $45-55^{\circ} \mathrm{C}$ means that at $55{ }^{\circ} \mathrm{C}$ almost complete destruction of associates occurs, and effective size of $\mathbf{1}$ and $\mathbf{2}$ at this temperature corresponds to the monomeric molecules size. Assuming that the number of molecules in the associate is in proportion to its size, at temperatures near to room temperature $\left(19-25^{\circ} \mathrm{C}\right)$ methylpheophorbide $a \mathbf{1}$ associates consist of an average of 4-5 molecules, and when the temperature is lowered to $10^{\circ} \mathrm{C}$ the association degree increases as expected, (the degree of association at this temperature 8-14). Anthracene at the same temperature range forms associates no more than 2-3 molecules (see Table 1).

\section{Conclusion}

Thus, at this work the methylpheophorbide $a$ behavior in solution was studied by diffusion ordered NMR spectroscopy (DOSY), and its molecules association degree were estimated using of the dependence on temperature of methylpheophorbide $a$ effective size. A significant decrease of the methylpheophorbide $a$ effective size as the temperature rises was observed. At temperatures of $45-55{ }^{\circ} \mathrm{C}$ particle sizes vary slightly, what corresponds to the almost complete destruction of methylpheophorbide associates. It was found that methylpheophorbide $a$ associates consist of an average of 4-5 molecules at room temperature.

Acknowledgements. The study was performed using the equipment of the Center for Shared Use of Scientific Equipment "Khimiya" of the Institute of Chemistry, Komi Science Center, Ural Branch of the Russian Academy of Sciences.

\section{References}

1. Gurinovich G.P., Sevchenko A.N., Solovyov K.N. Spectroscopy of Chlorophyll and Related Compounds, Minsk:
Nauka i Tekhnologiya, 1968. 520 p. (in Russ.) [Engl. transl.: Nat. Tech. Informat. Serv. US Dept. of Commerce, Springfield, Virginia, 1971, 506 p.].

2. Berezin B.D. Coordination Compounds of Porphyrins and Phthalocyanine, Moscow: Nauka, 1978. 280 p. (in Russ.) [Березин Б.Д. Координачионные соединения порфиринов и фталоциианина, М.: Наука, 1978. 280 с.].

3. Berezin B.D., Berezin D.B. Chromophore Systems of Macrocycles and Linear Molecules, Moscow: Krasand, 2013. 240 р. (in Russ.) [Березин Б.Д., Березин Д.Б. Хромофорные системы макроциклов и линейных молекул, М.: Красанд, 2013. 240 c.].

4. Kharlamov S.V.,Latypov Sh.K.Russ. Chem.Rev. 2010, 79, 635653. http://dx.doi.org/10.1070/RC2010v079n08ABEH004148

5. Chernysh Yu.E., Volynkin V.A., Panyushkin V.T., Kondakov V.I., Korobov M.S., Borodkin G.S. Russ. Chem. Rev. 2005, 74, 317-340.

6. Johnson C.S. Jr. Prog. Nucl. Magn. Reson. Spectrosc. 1999, 34, 203-256.

7. Morris G.A. Diffusion-Ordered Spectroscopy (DOSY). In: Encyclopedia of Nuclear Magnetic Resonance (D.M. Grant, R.K. Harris, Eds.), Chichester: John Wiley \& Sons Ltd., 2002, p. 35-44.

8. Galiullina L., Nikolaev A., Semenov V., Reznik V., Latypov S. Tetrahedron 2006, 62, 7021-7033.

9. Kharlamov S.V., Ziganshina A.Y., Aganov A.V., Konovalov A.I., Latypov S.K. J. Incl. Phenom. Macrocycl. Chem. 2007, $58,389-398$.

10. Latypov S.K., Kozlov A.V., Hey-Hawkins E., Balueva A.S., Karasik A.A., Sinyashin O.G. J. Phys. Chem. A 2010, 114, 2588-2596.

11. Stolypko A.L., Belykh D.V., Startseva O.M. Macroheterocycles 2015, 8, 47-49.

12. Bichan N.G., Tyulyaeva E.Yu., Lomova T.N., Semeikin A.S. Russ. J. Org. Chem. 2014, 50, 1361-1368.

13. Johnston M.R., Latter M.J. J. Porphyrins Phthalocyanines 2001, 6, 757-762.

14. Bichan N.G., Tyulyaeva E.Yu., Khodov I.A., Lomova T.N. $J$. Mol. Struct. 2014, 1061, 82-89.

15. Khodov I.A., Nikiforov M.Y., Alper G.A., Mamardashvili G.M., Mamardashvili N.Z., Koifman O.I. J. Mol. Struct. 2015, 1081, 426-430.

16. Durot S., Flamigni L., Taesch J., Dang T.T., Heitz V., Ventura B. Chem. Eur. J. 2014, 20, 9979-9990.

17. Khodov I.A., Alper G.A., Mamardashvili G.M., Mamardashvili N.Z. J. Mol. Struct. 2015, 1099, 174-180.

18. Arai S., Niwa D., Nishide H., Takeoka S. Org. Lett. 2007, 9, 17-20.

19. Patent RF 2180342, 2002.

20. The Chemist's Handbook, Vol. 1 ( $3^{\mathrm{d}}$ ed.), Moscow: Khimiya, 1971. 1070 p. (in Russ.) [Справочник химика, Т. 1 ( $3^{\mathrm{e}}$ изд.), М.: Химия, 1971. 1070 с.]. 